\title{
A lectin histochemical study on carbohydrate moieties of the gonadotropin-like substance in the epithelial cells of Hatschek's pit of Branchiostoma belcheri
}

\author{
Y. Q. Fang ${ }^{1} \&$ U. Welsch ${ }^{2}$ \\ 'Third Institute of Oceanography, SOA, Daxue Rd. No. 178, Xiamen 361005, \\ People's Republic of China \\ ${ }^{2}$ Anatomische Anstalt, Pettenkoferstr. 11, D-80336 München, Germany
}

\begin{abstract}
The present light microscopic lectin histochemical study suggests for the first time that the vertebrate gonadotropin-like substance in the basal part of the epithelial cells of Hatschek's pit is a sialic acid-containing glycoprotein. The binding intensity of the epithelial cells in Hatschek's pit to 6 lectins (Limulus polyphemus agglutinin (LPA), Wheat germ agglutinin (WGA), Helix pomatia agglutinin (HPA), Concanavalin A (Con A), Ulex europaeus agglutinin I (UEA I) and Ricinus communis agglutinin I (RCA I)) indicate that the carbohydrate composition of the gonadotrophic glycoprotein is similar to that of mammals and fish, and that $\mathrm{N}$-acetyl-D-galactosamine, sialic acid, glucosamine, D-mannose and L-fucose are components of the carbohydrate portion.
\end{abstract}

\section{INTRODUCTION}

Since the original electron microscopical observation by Tjoa \& Welsch (1974) of small granules and vesicles at the basis of the epithelial cells of Branchiostoma lanceolatum, growing evidence for an endocrine function of this organ has accumulated. Chang et al. (1982) demonstrated for the first time using an immunocytochemical technique that Hatschek's pit in Branchiostoma belcheri can synthesize a mammalian LH-like gonadotropic substance. Using both cytological and endocrinological experimental methods, Fang \& Qi (1989) demonstrated that certain epithelial cells of Hatschek's pit may be the primitive gonadotropic cells of Branchiostoma. More recent work has demonstrated, by means of immunocytochemical techniques, that Hatschek's pit elaborates mammalian and fish gonadotropin-like substances (Nozaki \& Gorbman, 1992; Fang, 1993). Biochemical analyses indicate that the glycoprotein gonadotropic hormones of vertebrates contain sialic acid and other carbohydrates (Burzawa-Gerard \& Fontaine, 1972). Sialic acid may be essential for the biological activity of gonadotropin (Grimek et al., 1976; Grimek et al., 1979). So far, no attempts have been made to characterize the gonadotropic substance in Hatschek's pit of Branchiostoma. It is not known whether the gonadotropin of Branchiostoma is also a glycoprotein, and whether its carbohydrate composition is similar to that of vertebrates. We used LPA (Limulus polyphemus agglutinin; Roche et al., 1975; Quatacker et al., 1990) for the histochemical detection of sialic acid in the glycoproteins of Hatschek's pit. LPA has been described to provide a means of identifying FSH 
(follicle stimulating hormone)-producing cells in mammalian pituitaries (Komuro \& Shioda, 1981). In addition, other lectins (WGA, HPA, Con A, UEA I and RCA I) have been used in the present study for further characterization of the secretory product of Hatschek's pit. Lectin histochemical techniques have been successfully applied to the analysis of secretory products in other endocrine systems (Komuro, 1987; Perez \& FernandezLebrez 1989). The purpose of the present study is to understand the biochemical characteristics of Branchiostoma's gonadotropin and to provide new evidence for the evolution of this glycoprotein hormone.

\section{MATERIAL AND METHODS}

Branchiostoma belcheri Gray (Amphioxus) were collected during winter and spring along the Qiontou coast, Tongan Country, Xiamen, in southern China. A total of 20 animals of both sexes, ranging from 47 to $56 \mathrm{~mm}$ in length, were used for this study.

The animals were fixed for $24 \mathrm{~h}$ in freshly prepared Bouin's solution; the tissue samples were dehydrated through a graded ethanol series and subsequently embedded in paraplast. Serial sections of 2-5 $\mu \mathrm{m}$ were mounted on glass slides. Sections that included Hatschek's pit were identified with a low magnifying microscope and selected for light microscopic carbohydrate histochemical staining.

\section{Lectin histochemistry}

Limulus polyphemus agglutinin (LPA), Wheat Germ agglutinin (WGA), Helix pomatia agglutinin (HPA), Concanavalin A (Con A), Ricinus communis agglutinin I (RCA I) and Ulex europaeus agglutinin I (UEA I) labeled with peroxidase (PO) were obtained from Sigma (München, Germany) and used in this study. Deparaffinized sections were incubated with the peroxidase labeled lectins (POLT) using a 1:25 or 1:40 dilution made with $0.05 \mathrm{M}$ Tris Buffer Saline (TBS), pH 7.6 for $1 \mathrm{~h}$ at room temperature. After washing with TBS, all sections were immersed in $3^{\prime}, 3^{\prime}$-diaminobenzidine (DBA, $0.5 \mathrm{mg} / \mathrm{ml}$ ) $-\mathrm{H}_{2} \mathrm{O}_{2}$ $(0.005 \%)$ for $10 \mathrm{~min}$, rinsed with distilled water, dehydrated and mounted.

The specificity of the obtained staining was tested by preincubating the lectins in a solution of the appropriate inhibitory sugar: D-mannose for Con A, L-fucose for UEA I, Dgalactosamine for HPA; the specificity of LPA was tested according to Komuro \& Shioda (1981). The concentration of the inhibitory sugar was $0.3 \mathrm{M}$. All inhibitory sugars were purchased from Sigma. Furthermore, the activity of endogenous peroxidase was checked by tissue sections reacting with $\mathrm{DAB}$ only.

\section{RESULTS}

In Branchiostoma belcheri, Hatschek's pit consists of three kinds of epithelial cells (Fang \& Qi, 1989): (1) epithelial cells in the depth of the pit; (2) irregularly-shaped cells; (3) ciliated mucous cells. The results obtained from analysis of the lectin binding pattern in Hatschek's pit are summarized in Table 1. It became clear that specific binding sites of 6 lectins (LPA, HPA, WGA, ConA, UEA I, RCA I) are to be found in the epithelium of Hatschek's pit of both sexes; no sex difference was found. The following text refers only to the epithelial cells in the depth of the pit ("deep" cells), which are of endocrine function. 
Table 1. Lectin binding sites in the Hatschek's pit of Branchiostoma belcheri

\begin{tabular}{|llllllll}
\hline $\begin{array}{l}\text { Binding site in } \\
\text { Hatschek's pit }\end{array}$ & & LPA & HPA & $\begin{array}{r}\text { Lectin } \\
\text { WGA }\end{array}$ & Con A & UEA I & RCA I \\
\hline $\begin{array}{l}\text { Epithelial } \\
\text { cells in the } \\
\text { depth of the pit }\end{array}$ & Cytoplasm & +++ & +++ & +++ & +++ & ++ & \pm \\
$\begin{array}{l}\text { Irregularly } \\
\text { shaped cells }\end{array}$ & Cytoplasm & - & - & ++ & - & - & - \\
$\begin{array}{l}\text { Ciliated } \\
\text { mucous } \\
\text { cells }\end{array}$ & Cytoplasm & - & - & ++ & + & - & - \\
- No staining; + Light staining; ++ to +++ Higher staining intensity & & & & \\
\hline
\end{tabular}

1. LPA-PO bound strongly to the apical and basal cytoplasm in the deep parts of Hatschek's pit. The cells of the lateral walls of Hatschek's pit reacted weakly or not at all (Figs 1a, 2). 2. HPA-PO was also strongly bound to the apical and basal cytoplasm of the epithelial cells in the depth of the pit (Fig. 1b). 3. WGA-PO bound strongly to granules in the apical cytoplasm and to the basal part of epithelial cells of Hatschek's pit (Fig. 1c, d). 4. Con A-PO labeled strongly or moderately the cytoplasm and cell periphery of the deep epithelial cells. 5. For UEA I-PO there was a moderate but specific binding in the apical cytoplasm and in the secretory granules of the basal parts of the deep epithelial cells. 6 . RCA I-PO occasionally bound faintly to the cytoplasm and cellular periphery in the basal parts of the deep epithelial cells. The LPA-PO binding intensity in the basal parts of the epithelial cells of Hatschek's pit in the different stages of the gonadal development exhibited differences. In animals with stage I gonads, the LPA-specific binding intensity in the basal parts of the epithelial cell is not so strong (Fig. 2) as in animals with stage IV gonads (Fig. 1a).

\section{DISCUSSION}

The investigation of Mazzuca et al. (1977) and Yamada \& Shimizu (1979) have shown that LPA can be used to demonstrate the presence of sialic acid residues in peptides in various cells and tissues. Accordingly, we used this lectin for detection of sialic acid residues in Hatschek's pit of Branchiostoma, which has been claimed to produce gonadotropic hormones (Chang et al., 1982; Nozaki \& Gorbman, 1992; Fang, 1993). Sialic acid is essential for biological activity of vertebrate gonadotropin (Grimek et al., 1976; Grimek et al., 1979). Therefore, LPA, which has been used for localisation of FSH-secreting cells in the mammalian adenohypophysis (Komuro \& Shioda, 1981), has also been used for localisation of gonadotropic cells in amphioxus. LPA exhibits strong binding in the cytoplasm of the epithelial cells in the depth of Hatschek's pit. In the controls these cells did not bind LPA. No staining occurred in the other cell types of Hatschek's pit. The LPA-binding site is coincident with the region of previously established localization of assumed gonadotropic cells of Branchiostoma by electron microscopy and physiological methods (Fang 


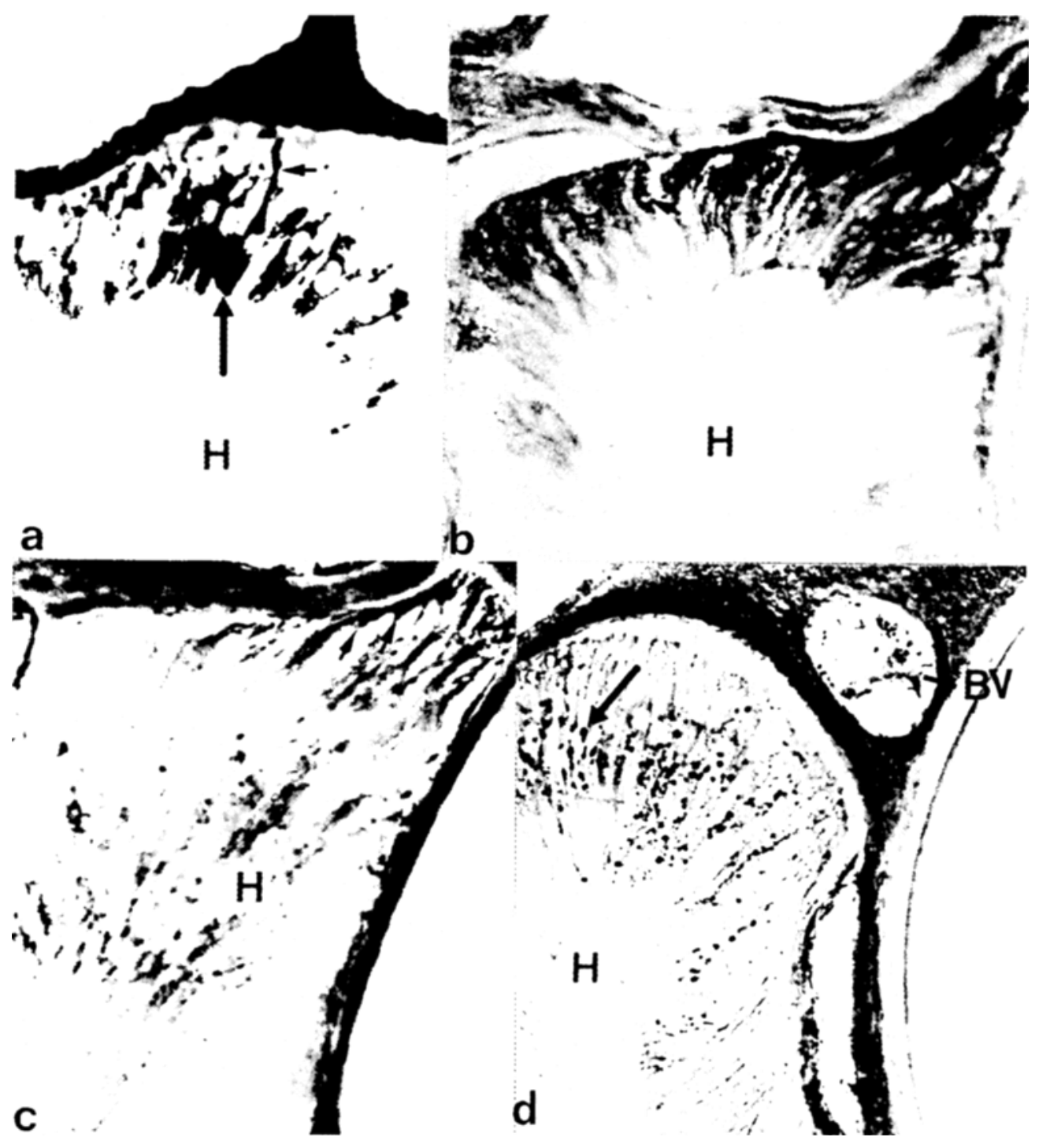

Fig. 1. Branchiostoma belcheri $(a-d)$. Cross sections through the head region with positive lectin binding at the epithelial cells at the bottom of Hatschek's pit (H). a Strong binding of LPA to the cytoplasm (thick arrow) including its basal part (thin arrow) of the epithelial cells. Positive reaction also in the subepithelial connective tissue; stage IV of the ovarian development (920: 1). b Strong binding of HPA mainly to the basal parts of the epithelial cells (arrows) $920: 1\}, c$ and $d$ WGA binding. $c$ WGA binding to granules in the apical cytoplasm of the epithelial cells; arrows: basal reaction; $d$ WGA binding to granules in the cytoplasm of the epithelial cells is of strong intensity (arrow); BV: Blood vessel (920:1) 


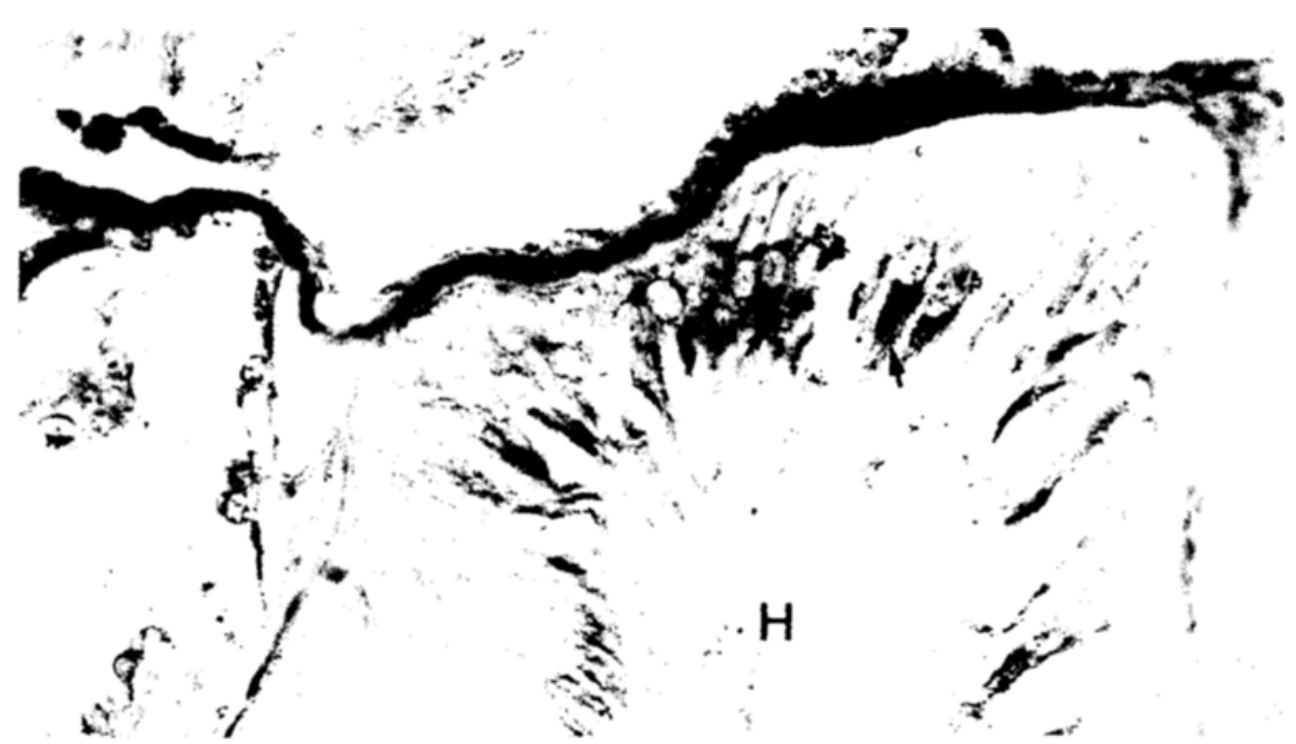

Fig. 2. Branchiostoma belcheri. Stage I of the ovarian development. LPA binding to the epithelial cells at the bottom of Hatschek's pit $(\mathrm{H})$. Binding occurs predominantly in the apical cytoplasm (arrows), possibly in the Golgi region (920:1)

\& Qi, 1989) as well as immunocytochemical localization using antibodies of mammalian and fish gonadotropin (Chang et al., 1982; Nozaki \& Gorbman, 1992; Fang, 1993). By demonstrating LPA-binding to epithelial cells in Hatschek's pit, it appears possible to suggest that Branchiostoma's gonadotropin, like that of vertebrates, is also a sialic acid-containing glycoprotein hormone. The binding pattern of HPA, WGA, Con A and UEA I in Hatschek's pit is similar to that of LPA, giving a strong or moderate binding reaction. It is known that HPA recognizes N-acetyl-D-galactosamine (Hammarström et al., 1977; Debray et al., 1981); WGA recognizes N-acetyl-D-glucosamine (Spicer \& Schulte, 1992; Araujo et al., 1993); Con A recognizes D-mannose (Goldstein \& Poretz, 1986); and UEA I recognizes L-fucose (Sugii et al., 1982; Araujo et al., 1993). This observation indicates, in addition to sialic acid, the presence of other carbohydrates in Branchiostoma's gonadotropin, including D-galactosamine, D-glucosamine, D-mannose and L-fucose. This situation is similar to that of the vertebrate gonadotropin. There is a difference concerning the presence of fucose, as indicated by the binding of UEA I which is not present in mammalian FSH and fish gonadotropin; mammalian LH, however, contains fucose (Burzawa-Gerard \& Fontaine, 1972). It is interesting to note that RCA I, which recognizes galactose, bound only occasionally and faintly to basal epithelial cells of Hatschek's pit. This observation corresponds to the findings of Burzawa-Gerard \& Fontaine (1972) according to which galactose is not a component of vertebrate gonadotropin. It appears as though in spite of the vast phylogenetic differences between Branchiostoma and teleosts and mammals, the gonadotropins in these groups are comparatively similar.

Branchiostoma's gonadotropin seems to have no species specificity (Fang \& Wang, 1984), and the molecular structure of Branchiostoma's gonadotropin possibly resembles 
that of mammal and fish (Fang, 1993). It appears plausible to speculate that gonadotropin is an ancient hormone occurring in both cephalochordates and vertebrates, lending support to Nielsen's concept of Notochordata (1995). The present study also supports the notion of Chang et al. (1982) and Nozaki \& Gorbman (1992) that an original function of Hatschek's pit, which is obviously the precursor of the vertebrate adenohypophysis (Tjoa \& Welsch, 1974), was the control of gonadal development.

In respect of the question in which way the endocrine secretory product of Hatschek's pit may be transported to its target organs, the gonads, we assume, that it is initially discharged by exocytosis at the basal plasma membrane of the epithelial cells. Presumably, it traverses the basal lamina and the narrow connective tissue space towards the nearby located blood vessels.

\section{LITERATURE CITED}

Araujo, A. C. G., Souto-Padron, T. \& Souza, W. de, 1993. Cytochemical localization of carbohydrate residues in microfilariae of Wuchereria bancrofti and Brugia malayi. - Cytochemistry 41,571-578

Burzawa-Gerard, E. \& Fontaine, Y. A., 1972. The gonadotropins of lower vertebrates. - Gen. comp. Endocrinol. (Suppl.) 3, 715-728.

Chang, C. Y., Zhu, Y. T. \& Cheng, D. Y., 1982. Immunocytochemical demonstration of luteinizing hormone (LH) in Hatschek's pit of amphioxus (Branchiostoma belcheri Gray). - Kexue Tongbao 27, $1233-1234$.

Debray, H., Decout, D., Strecher, G., Spik, G. \& Montreuil, J., 1981. Specificity of twelve lectins towards oligosaccharides and glycopeptides related to N-glycosylproteins. - Eur. J. Biochem. 117, 41.

Fang, Y. Q., 1993. Immunocytochemical localization of fish gonadotropin (GTH) in the brain vesicle and Hatschek's pit of amphioxus. - Chinese Sci. Bull. 38, 1747-1751.

Fang, Y. Q. \& Qi, X., 1989. Ultrastructural study of the Hatschek's pit epithelial cells of amphioxus. - Sci. China (B) 32, 1465-1472.

Fang, Y. Q. \& Wang, L., 1984. The preliminary study of homogenate of the wheel organ and Hatschek's pit of amphioxus on testicular development in young toad (Bufo malanostictus). - Acta Biol. exp. sin. 17, 115-117.

Goldstein, I. J. \& Poretz, R. D., 1986. Isolation, physicochemical characterization, and carbohydratebinding specificity of lectins. In: The lectins. Ed. by I. E. Liener, N. Sharon \& I. J. Goldstein. Acad. Press, Orlando, Fla, 33.

Grimek, H. J., Nuti, L. C., Nuti, K. M. \& McShan, W. H., 1976. Effect of neuraminidase treatment on the biological activity of highly purified ovine FSH and LH in hypophysectomized immature male and female rats. - Endocrinology 98, 105-110.

Grimek, H. J., Gorski, J. \& Wentworth, B. C., 1979. Purification and characterization of bovine follicle-stimulating hormone: Comparison with ovine follicle-stimulating hormone. - Endocrinology 104, $140-147$.

Hammarström, S., Murghy, L. A., Goldstein, I. J. \& Etzler, M. E., 1977. Carbohydrate binding specificity of four N-acetyl-D-galactosamine-"specific" lectins: Helix pomatia A hemagglutinin, Soybean agglutinin, Lima bean lectin, and Dolichos biflorus lectin. - Biochemistry 16, 2750.

Komuro, M., 1987. Presence of glycoconjugates in prolactin granules of male rats, - Cell Tissue Res. $250,181-184$.

Komuro, M. \& Shioda, T., 1981. Localization of sialic acid-containing hormones in GTH cell and ACTH cell of the rat anterior pituitary. - Cell Tissue Res. 220, 519-528.

Mazzuca, M., Roche, A. C., Lhermitte, M. \& Koussel, P., 1977. Limulus polyphemus lectin site in human bronchial mucosa. - J. Histochem. Cytochem. 25, 470-473.

Nielsen, C., 1995. Animal evolution. Oxford Univ. Press., London, $467 \mathrm{pp}$.

Nozaki, M. \& Gorbman, A., 1992. The question of functional homology of Hatschek's pit of amphioxus (Branchiostoma belcheri) and the vertebrate adenohypophysis. - Zool. Sci. 9, 387-395.

Perez, J. \& Fernandez-Lebrez, P., 1989. Immuno- and lectin-electron-microscopic investigation of the neural lobe of the hypophysis in the snake Natrix maura. - Cell Tissue Res. 258, 547-554. 
Quatacker, J. R., Annaert, W. G. \& De Potter, W. P., 1990. Detection of sialic acid residues in the axonal reticulum of rat superior cervical ganglion cells by lectin-gold cytochemistry. - J. Histochem. Cytochem. 38, 1445-1449.

Roche, A. C., Schauer, R. \& Monsigny, M., 1975. Protein-sugar interactions purification by affinity chromatography of limulin and N-dcylneur-aminidyl-binding protein. - Febs Lett. 57, 245-249.

Spicer, S. S. \& Schulte, B. A., 1992. Diversity of cell glycoconjugates shown histochemically: A perspective. - J. Histochem. Cytochem. 40, 1-38.

Sugii, S., Kabat, E. A. \& Baer, H. H., 1982. Further immunochemical studies on the combining sites of Lotus tetragonolobus and Vlex europaeus [ and If lectins. - Carbohydr. Res. 99, 99.

Tjoa, L. T. \& Welsch, U., 1974. Electron microscopical observation on Kölliker's and Hatschek's pit and on the wheel organ in the head region of amphioxus (Branchiostoma lanceolatum). - Cell Tissue Res. 153, 175-187.

Yamada, K. \& Shimizu, S., 1979. The use of peroxidase-labelled Limulus polyphemus agglutinin for the histochemistry of sialic acid-containing glycoproteins in light microscopy. - Histochem. J. 11 , $457-471$ 